\title{
Some tricks for lumen-apposing metal stents: placement in benign esophageal strictures and a technique for reuse after complete misplacement
}

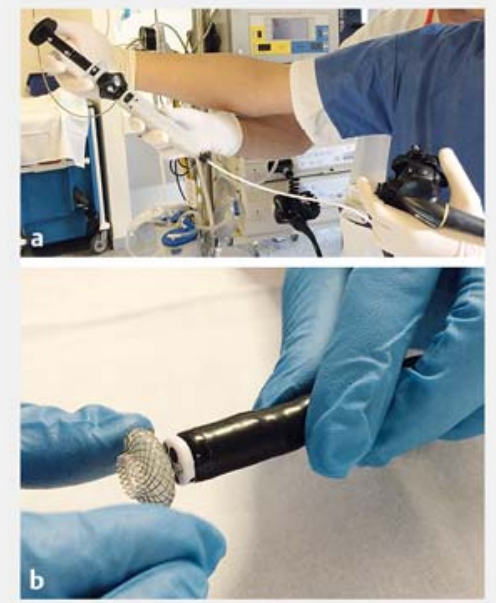

- Fig. 1 Photographs showing: a the device protruding about $30 \mathrm{~cm}$ above the working channel of a therapeutic endoscope, meaning it takes two people to operate it; $\mathbf{b}$ the lumen-apposing metal stent being drawn into the working channel of the therapeutic endoscope.

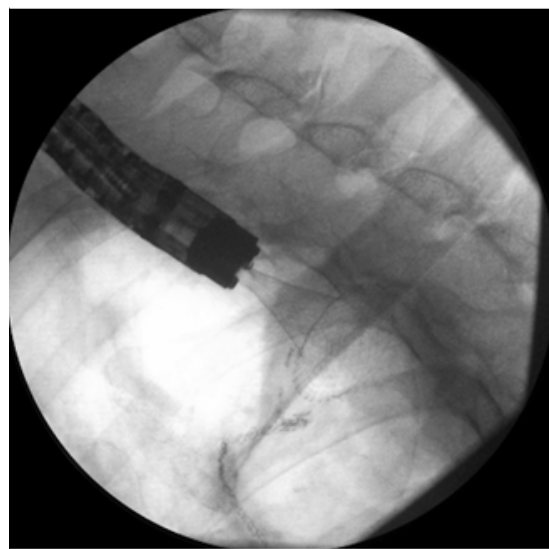

- Fig. 2 Radiographic image showing release of the distal flap of the lumenapposing metal stent during repositioning from the working channel of a therapeutic gastroscope.

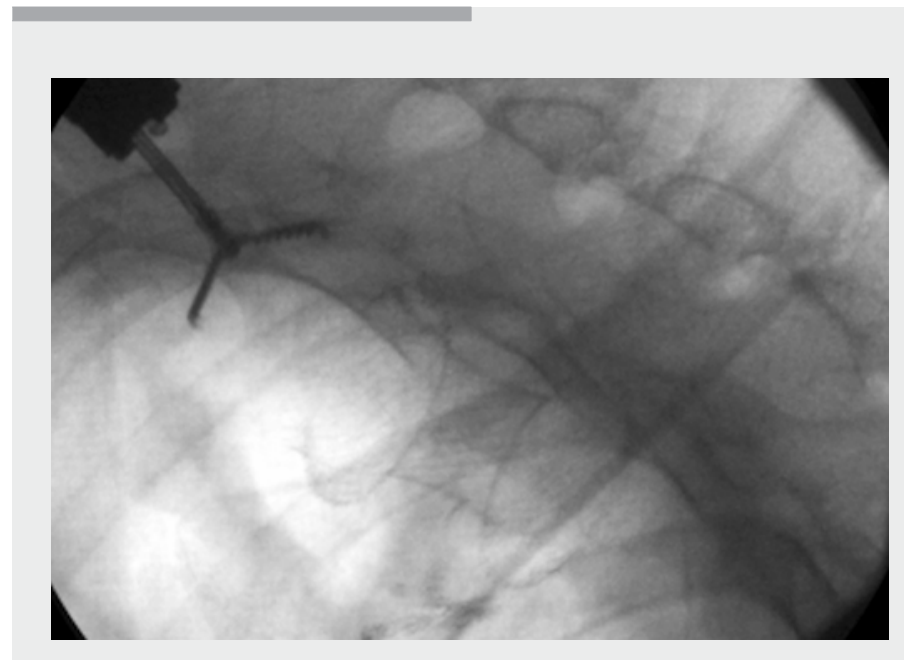

$\checkmark$ Video 1 This video shows placement of a lumen-apposing metal stent using a directvision endoscope and a technique to reposition this type of stent after complete misplacement.

Lumen-apposing metal stents (LAMSs) are increasingly being used in our dayto-day practice. Endoscopists are beginning to gain experience not only in their placement but also in the errors or complications that can occur during their release, which may result in failure of the procedure or the need to use a new stent, with a consequent increase in the costs of the procedure. One specific case is complete malpositioning of a stent, meaning the complete opening of the metal without it reaching the target that is being pursued. In most cases, this forces one into having to use a new LAMS or another type of stent.

While LAMSs are designed to be released with an echoendoscope, there are some situations in which we need to release the stent under direct frontal view, for example in benign esophageal strictures $[1,2]$. However, the problem we find is that the device is designed for use with an echoendoscope and not with a therapeutic endoscope [3] ( $\$$ Fig. 1 a).
- Video 1 shows two small tricks to help in these situations. The first case shows step by step how to place and release a LAMS with a therapeutic endoscope. The second case shows how a LAMS can be reused after it has been misplaced, using the working channel to collapse the stent ( $\vee$ Fig. 1 b), thereby allowing reuse of the LAMS ( $>$ Fig. 2 ) and avoiding an increase in the costs of the procedure.

Our video is based on benign esophageal stricture, but may be useful in many other indications where LAMSs are used, such as complicated pancreatitis with walled-off pancreatic necrosis (WON) [4]. We therefore believe that this video can help colleagues who find themselves in similar situations to those described.

Endoscopy_UCTN_Code_CPL_1AH_2AD

\section{Competing interests}

None 
Ramon Sanchez-Ocana ${ }^{1}$, Marcos JimenezPalacios $^{2}$, Ana Carbajo-Lopez ${ }^{1}$, Irene PenasHerrero $^{3}$, Paula Gil-Simon ${ }^{1}$, Carlos de la SernaHiguera ${ }^{1}$, Manuel Perez-Miranda ${ }^{1}$

1 Gastroenterology and Endoscopy Unit, Hospital Universitario Rio Hortega, Valladolid, Spain

2 Gastroenterology and Endoscopy Unit, Complejo Asistencial de Leon, Leon, Spain

3 Gastroenterology and Endoscopy Unit, Hospital General Rio Carrion, Palencia, Spain

\section{Corresponding author}

Ramon Sanchez-Ocana, MD

C/Dulzaina s/n, 47014, Valladolid, Spain Fax: +34-983-420414

ramonsocana@gmail.com

\section{References}

[1] Yang D, Nieto JM, Sidiqqui A et al. Lumenapposing covered self-expandable metal stents for short benign gastrointestinal strictures: a multicenter study. Endoscopy 2017; 49: 327 - 333

[2] Irani S, Jalaj S, Ross A et al. Use of a lumenapposing metal stent to treat $\mathrm{Gl}$ strictures (with videos). Gastrointest Endosc 2017; 85: $1285-1289$

[3] Majumder S, Buttar NS, Gostout C et al. Lumen-apposing covered self-expanding metal stents for management of benign gastrointestinal strictures. Endosc Int Open 2016; 04: E96-E101

[4] Kumta NA, Doshi R, Reinoso PJJr. et al. Retrieval and reuse of a dislodged lumenapposing metal stent during endoscopic necrosectomy for pancreatic necrosis. Gastrointest Endosc 2016; 84: 364

\section{Bibliography}

DOI https://doi.org/10.1055/a-0915-1490

Published online: 4.6.2019

Endoscopy 2019; 51: E333-E334

(c) Georg Thieme Verlag KG

Stuttgart · New York

ISSN 0013-726X

\section{ENDOSCOPY E-VIDEOS}

https://eref.thieme.de/e-videos

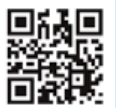

Endoscopy E-Videos is a free

回政: access online section, reporting on interesting cases and new techniques in gastroenterological endoscopy. All papers include a high quality video and all contributions are freely accessible online.

This section has its own submission website at https://mc.manuscriptcentral.com/e-videos 